Progress in Oceanography

September 2018, Volume 166, Pages 41-53

http://dx.doi.org/10.1016/i.pocean.2017.12.008

http://archimer.ifremer.fr/doc/00416/52790/

(c) 2017 Elsevier Ltd. All rights reserved.

\title{
Coccolith-derived turbidity and hydrological conditions in May in the Bay of Biscay
}

\author{
Perrot Laurie ${ }^{1}$, Gohin Francis ${ }^{1,{ }^{*}}$, Ruiz-Pino Diana ${ }^{2}$, Lampert Luis ${ }^{1}$, Huret Martin ${ }^{3}$, Dessier Aurélie ${ }^{4}$, \\ Malestroit Pascale ${ }^{1}$, Dupuy Christine ${ }^{4}$, Bourriau Paul ${ }^{5}$
}

1 IFREMER, DYNECO-PELAGOS, Centre Ifremer de Brest CS 10070, F-29280 Plouzane, France

${ }^{2}$ Laboratoire LOCEAN-CNRS/IPSL, Université de Paris VI, Paris, F-75005, France

${ }^{3}$ IFREMER, STH-LBH, Centre Ifremer de Brest CS 10070, F-29280 Plouzane, France

${ }^{4}$ Littoral Environnement et Sociétés (LIENSs), UMR 7266, CNRS-Université de La Rochelle, 2 rue

Olympe de Gouges, F-17042 La Rochelle Cedex 01, France

${ }^{5}$ IFREMER, EMH, rue de I'Ile d'Yeu BP 21105, F-44311 Nantes Cedex 03, France

* Corresponding author : Francis Gohin, email address : Francis.Gohin@ifremer.fr

\begin{abstract}
:
Coccolithophore blooms occur regularly from April to June in the Bay of Biscay where they have been observed for many years from ocean-colour imagery thanks to the ability of their calcite plates to scatter light. They are easily depicted on interpolated images of non-algal Suspended Particulate Matter (SPM) derived from satellite reflectance data in May, at the time of the PELGAS (PELagique GAScogne) annual surveys. Over the springs 2012 to 2015, the PELGAS surveys provided in-situ data on the turbidity throughout the water column and on the hydrological environment prevailing during the blooms in the vicinity of the continental shelf break. The satellite-derived SPM in the area of coccolithophore blooms was closely related to measured turbidity in the euphotic zone. The deep maxima of coccolithophore-derived biomass were well observed in the turbidity signal throughout the water column. Despite the recurrence of SPM patterns due to coccolithophores in the well-mixed waters over the shelf break in spring, the variability of the satellite-derived SPM and the turbidity profiles was particularly high during the four years studied. The year 2013 showed persistent blooms from mid-April to the end of May over large areas inside and outside the shelf waters, whereas no bloom was observed in 2014, neither on SPM images nor through turbidity profiles. The presence or absence of coccolithophore blooms during the years 2012-2015 seem related to the level of stratification of the water column, with more intense blooms occurring during mixed conditions. These results should improve classification of the PELGAS surveys from those occurring in a coccolith-rich environment, synonymous with mixed and cold waters, to those occurring in a coccolith-poor environment where surface waters are warmer and more stratified.
\end{abstract}




\section{Highlights}

- Offshore turbidity in May is associated with coccolithophores in the Bay of Biscay. Satellite-derived Suspended Particulate Matter and in-situ turbidity are well related. Turbidity profiles together with satellite data result in a better 3-D conception of the blooms. Absence of coccolithophores in May is associated with stronger stratification.

Keywords: Bay of Biscay, ocean colour, suspended particulate matter, turbidity, coccoliths, stratification 


\section{Introduction}

At the time of the PELGAS (PELagique GAScogne) ecosystem surveys, in May in the Bay of Biscay, phytoplankton-derived turbidity is often observed on different satellite products, such as the non-algal Suspended Particulate Matter (SPM) concentration (Gohin et al., 2005; Jafar-Sidik et al., 2017) provided by CMEMS (Copernicus Marine Environment Monitoring Service, http://marine.copernicus.eu/) or Calcite concentration (Balch et al., 2005) provided by NASA GSFC (Goddard Space Flight Center).

Patterns of high turbidity occur in the vicinity of the continental shelf break during the season when resuspension by waves is limited to shallow waters in the Bay of Biscay (Gohin et al., 2015) and cannot be the reason for high SPM patches isolated offshore. This turbidity is induced by phytoplankton in such high concentrations that it can only be attributed to coccolithophores, a group of calcifying phytoplankton. Coccolithophores produce a shell comprised of calcite scales called coccoliths that detach from the cell throughout the development of the bloom (Fritz, 1996, Fritz and Balch, 1999) or during their senescent phase. Coccolithophore blooms have a strong reflectance signal due to the light-scattering quality of coccoliths (Groom and Holligan, 1987) and they can be identified and quantified from remote-sensing by applying dedicated algorithms 
(Gordon et al., 2001; Balch et al., 2005). On a global scale, coccolithophore blooms have significant environmental impacts through the production of $\mathrm{CaCO}_{3}$ and dimethylsulfide (DMS), the increase of water albedo, as well as their key role in the ocean carbon flux (Westbroek et al., 1993, Brown and Yoder, 1994). Coccolithophores belong to the Prymnesiophyceae phytoplankton algae class and the majority of the species have a size betwenn 3 and $20 \mu \mathrm{m}$. Emiliania huxleyi is the most abundant coccolithophore in the modern ocean (Paasche, 2001) and the most important bloom-forming calcifier in the North Atlantic Ocean (Westbroek et al., 1993).

The phytoplankton phenology in spring in the Bay of Biscay (North-East Atlantic Ocean) is characterised by diatom blooms and, when dissolved silicate is depleted, by nanoplankton (Raitsos et al., 2006; Guillaud et al., 2008; Leblanc et al., 2009). Coccolithophore blooms frequently follow those of the diatoms although they also co-occur with other phytoplankton (Hopkins et al., 2015). The seasonal occurrence and the variability of coccolithophore blooms have been previously described in the northern part (Morozov et al., 2013) and along the continental slope of the Bay of Biscay (Beaufort and Heussner, 1999).

Due to their strong backscattering property, coccoliths act optically similarly to non-algal SPM commonly found over the continental shelf (Gohin et al., 2005, Gohin et al., 2015, Jafar-Sidik et al., 2017). As a consequence, satellite-derived SPM products can be used to investigate the variability of the coccolithophore blooms in the Bay of Biscay during a season (May) and a place (continental shelf break) where turbidity from resuspension of bottom sediment or from river supply of SPM does not occur at the surface layer.

Using satellite imagery, we can depict coccolithophore in the surface waters but the maxima abundance of coccolithophores in many oceanic regions is observed at the subsurface. During June 2004 in the northern Bay of Biscay high coccolithophore abundances were measured at the surface within the bloom patch $\left(>8.10^{6}\right.$ cells. $\left.\mathrm{L}^{-1}\right)$, but maximum values are reached at sub-surface levels with peaks at $40 \mathrm{~m}$ depth (Harlay et al. 2010). Beaufort et al. (2008) have also shown that coccolithophore species in the South-east Pacific (including Emiliania huxleyi, Gephyrocapsa spp. and Crenalithus spp.) grew preferentially at the deep chlorophyll maximum, and can be found at depth greater than $100 \mathrm{~m}$. An accurate vertical distribution of oceanic physical and biological parameters that integrates a variable deep layer depending on the transparency of the water is still 
one of the greatest challenges facing remote sensing: no satellite surface signal does not mean deeper occurrences do not occur.

What are the hydrological conditions needed to drive a strong and extended coccolithophore bloom over the Bay of Biscay? In the bay different physical mechanisms contribute to produce extended coccolithophore blooms. This is a region where a complex interchange occurs between ocean features and local processes at different temporal and spatial scales (Costoya, 2015). It is also subject to a highly seasonal and variable water circulation over the continental shelf due to a combination of wind-driven, tidally induced, and density-driven flows (Charria et al., 2013; Costoya, 2015). Mesoscale eddies can also regulate the vertical structure of coccolithophore blooms in the euphotic zone (Jin et al, 2016). Moreover, on the one hand, coccolithophore blooms seem to occur as stratification of the surface layer and the solar irradiance increase (Boyd et al., 2010; Leblanc et al., 2009), and, on the other hand, along the shelf break where coccolithophore blooms have been shown to be triggered and/or sustained by internal-tidal wave-formation leading to enhanced vertical mixing and the injection of inorganic nutrients to the surface waters (Groom and Holligan, 1987; Lampert et al., 2002; Sharples et al., 2009; Harlay et al., 2010).

In this work, we investigated the variability of the satellite-derived turbidity available at the surface in the Bay of Biscay together with profiles of in-situ turbidity in order to provide a 3-D conceptional framework of the coccolithophore blooms and to assess hydrological and stratification conditions that could favour these blooms.

\section{Material and Methods}

\subsection{Remote-sensing data}

Interpolated fields of chlorophyll-a (Chl-a) and non-algal SPM derived from satellite reflectance were used respectively to monitor the total phytoplankton biomass and the surface turbidity. Chl-a was obtained from the application of 2 look-up tables (LUT) to the spectral remote-sensing reflectance (Rrs) of MODIS-Aqua and VIIRS projected on a grid at a resolution of $1 \mathrm{~km}$ (Gohin et al., 2002). SPM was estimated following the semi-analytical algorithm proposed initially by Gohin et al. (2005) and validated on in-situ data collected in the coastal waters of the Bay of Biscay, the 
English Channel and the western Mediterranean Sea. This satellite product has been evaluated in details in Jafar-Sidik et al. (2017) through comparisons to a large set of in-situ measurements of turbidity and SPM captured at the location of the Liverpool Bay mooring in the coastal waters of the Irish Sea.

In this procedure, absorption and backscattering by phytoplankton were derived from preliminary estimations of Chl-a concentrations. Then, SPM was obtained from radiance at $550 \mathrm{~nm}$ and 670 $\mathrm{nm}$. Depending on the level of the retrieved SPM, the final SPM was chosen at $550 \mathrm{~nm}$ if both SPM concentrations (at $550 \mathrm{~nm}$ and $670 \mathrm{~nm}$ ) were less than $4 \mathrm{~g} . \mathrm{m}^{-3}$. In the cases where SPM concentration (at $550 \mathrm{~nm}$ and $670 \mathrm{~nm}$ ) was more than $4 \mathrm{~g} . \mathrm{m}^{-3}, \operatorname{SPM}(670)$ was chosen. Always following the method proposed by Gohin et al. (2005),

total SPM was estimated by formula (1) :

Total SPM = non-algal SPM $+0.234 \mathrm{Chl}-\mathrm{a}^{0.57}$

Interpolated images were used to investigate the variability of the blooms because of the presence of clouds that may hamper the processing of marine reflectance. Interpolation by kriging, widely used in the domain of spatial analysis, provides the best linear unbiased estimator given a covariance function. A space-time autocorrelation is considered for Chl-a and SPM. Interpolations are carried out at each pixel on the $1 \mathrm{~km}$ grid of the images. Satellite data observed within 5 days before and 5 days after the day of interest are selected to build the data sets used for the interpolation (Saulquin et al., 2011).

Several methods are available for identifying coccoliths on ocean colour images when their signal is dominant on the remote-sensing reflectance. They can be detected purely from reflectance spectra (Moore et al. 2012) or from specific temporal characteristics. When mineral SPM in resuspension or river plumes are present in coastal waters, a purely spectral method is unable to provide an identification of coccolithophores. It is therefore recommended to take advantage of the differences in the temporal variability of the reflectance between river outputs, resuspension and coccolithophore blooms, to discriminate their signatures on satellite imagery (Shutler et al., 2010). In our study area in May, storms and other climatic events cannot be the reason for the high SPM patches observed offshore on satellite images. These very high levels of turbidity are therefore induced by phytoplankton. When these high turbidity levels are not associated with elevated 5 
concentrations of chlorophyll-a (i.e. generally no more than $2 \mathrm{mg} \mathrm{m}^{-3}$ ), diatoms are unlikely to be the cause of these features that can only be attributed to calcifying species, and particularly to coccolithophores.

\subsection{PELGAS observations}

The in-situ data were collected during the yearly PELGAS surveys and compared to the satellite products. These surveys cover the periods from April $27^{\text {th }}$ to May $23^{\text {rd }}$ in 2012 , April $28^{\text {th }}$ to May $22^{\text {nd }}$ in 2013, April $26^{\text {th }}$ to June $3^{\text {rd }}$ in 2014 , and May $1^{\text {st }}$ to May $29^{\text {th }}$ in 2015. 87 stations were sampled in 2012, 72 in 2013, 94 in 2014 and 99 in 2015 along transects from the coast to the shelfbreak (Fig.1). The hydrological environment was described by continuous CTD vertical profiles of temperature, salinity and density (Seabird SBE 19+V2). Niskin bottles were closed at surface, deep chlorophyll maximum when existing, and below the thermocline. In-situ SPM and PIM (Particulate Inorganic Matter) concentrations were derived from 1 to 2 liters of water filtered through $47 \mathrm{~mm}$ $\mathrm{GF} / \mathrm{F}$ filters (Whatman, $0.7 \mu \mathrm{m}$ ) under a vacuum pressure $<10 \mathrm{~mm} \mathrm{Hg}$. Filters were previously combusted at $490^{\circ} \mathrm{C}$ for $2 \mathrm{~h}$ to eliminate their subsequent organic carbon content and then weighed. After sample filtration, each filter was rinsed twice with distilled water to remove salt, dried at $60^{\circ} \mathrm{C}$ for $12 \mathrm{~h}$ and weighed. To determine the proportion of particulate inorganic matter (PIM) filters were combusted at $490^{\circ} \mathrm{C}$ for $2 \mathrm{~h}$ and then weighed.

Turbidity was measured by an Optical Backscatter Sensor OBS-3+ (Campbell Scientific), detecting scattered infra-red light between $140^{\circ}$ and $160^{\circ}$, mounted on the CTD probe. The turbidimeter was calibrated in 2012 and 2016 by Campbell Scientific on styrenedivinyl benzene micro-spheres. The turbidity is expressed in NTU (Nephelometric Turbidity Unit).

The turbidity profiles were influenced by the scattering of sunlight by detached coccoliths and/or coccospheres in the offshore waters.

A fluorimeter (WETStar from WET Labs) was also mounted on the CTD probe to provide an indicator of the phytoplankton biomass throughout the water column. Yearly calibration was carried 
out based on in-situ chl-a measurements from the Niskin bottles sampling. These were determined using a fluorimeter Turner TD 700 (Aminot and Kérouel, 2005; Lorenzen , 1967).

Nutrients (silicate, phosphate and nitrate) were analysed according to the classical methods described by Strickland and Parsons (1972). The mesozooplankton community was collected by vertical WP2 hauls (0.25 $\mathrm{m}^{2}$ opening, $200-\mu \mathrm{m}$ mesh-size) from $100 \mathrm{~m}$ depth (or maximum depth) to the surface and preserved in $10 \%$ formaldehyde (final concentration). The abundance (individuals. $\mathrm{m}^{-3}$ ) of mesozooplankton was determined following the identification proposed by Rose (1933), as detailed in Dessier (2015).

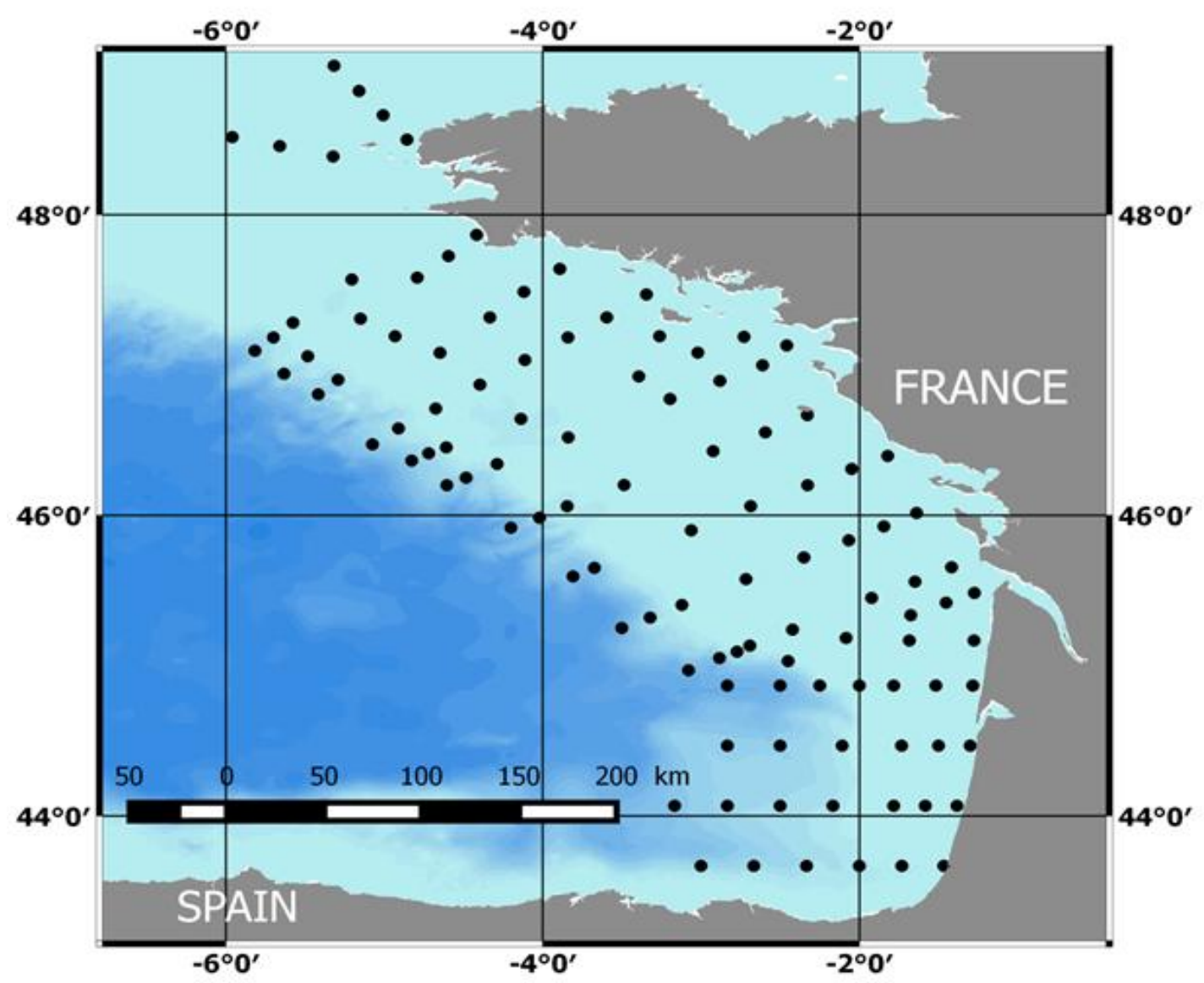

Fig. 1. Sampling stations performed during PELGAS surveys.

\subsection{Hydrology derived indices}

The Mixed Layer Depth (MLD), with criterion of delta sigma $=0.1$ (de Boyer Montégut et al, 
2004), and the Density Gradient Layer (DGL) were calculated from the density profiles (Fig. 2). Turbidity was integrated between the surface and the MLD $\left(\mathrm{T}_{\mathrm{MLD}}=\mathrm{EMBED}\right.$ Microsoft Equation $\left.3.08 \sum_{\text {MLD }}^{0}\left(t_{\max }-t_{\min }\right)\right)$, between the MLD and the DGL ( $\mathrm{T}_{\mathrm{DGL}}=$ EMBED Microsoft Equation 3.08 $\left.\sum_{b G L}^{M L D}\left(t_{\max }-t_{\min }\right)\right)$ and between the surface and the DGL as total integrated turbidity (TIT).

An index of stratification was calculated from the density profiles measured at each station. This index was defined as the mean of the density gradient between depth $\mathrm{z}$ in the surface layer and the bottom of the Density Gradient Layer.

Fig. 2. Diagram of the density profile with the terminology used in the text

\section{Results}

\subsection{Satellite data}

\subsubsection{The interpolated SPM images on coccolithophore blooms}

Interpolations of Chl-a and SPM have been carried out routinely for years at Ifremer providing daily images to different categories of users for the purpose of monitoring and model validation. Fig. 3 illustrates the application of the kriging method for May $8^{\text {th }} 2013$, at a time when the coccolithophore bloom was at its largest extent during the four years studied. Looking at the 11 daily SPM images used for the interpolation, between May $3^{\text {rd }}$ and May $13^{\text {th }}$, we observe a relatively slow evolution of SPM levels. Compared to the phytoplankton biomass that usually varies very quickly under sunny conditions or to resuspended SPM that is driven by waves and 
tides, the coccolith-derived SPM is more stable. This could be explained by the slow growth of the bloom and the continuous separation of coccoliths that gently sink down to deeper layers.

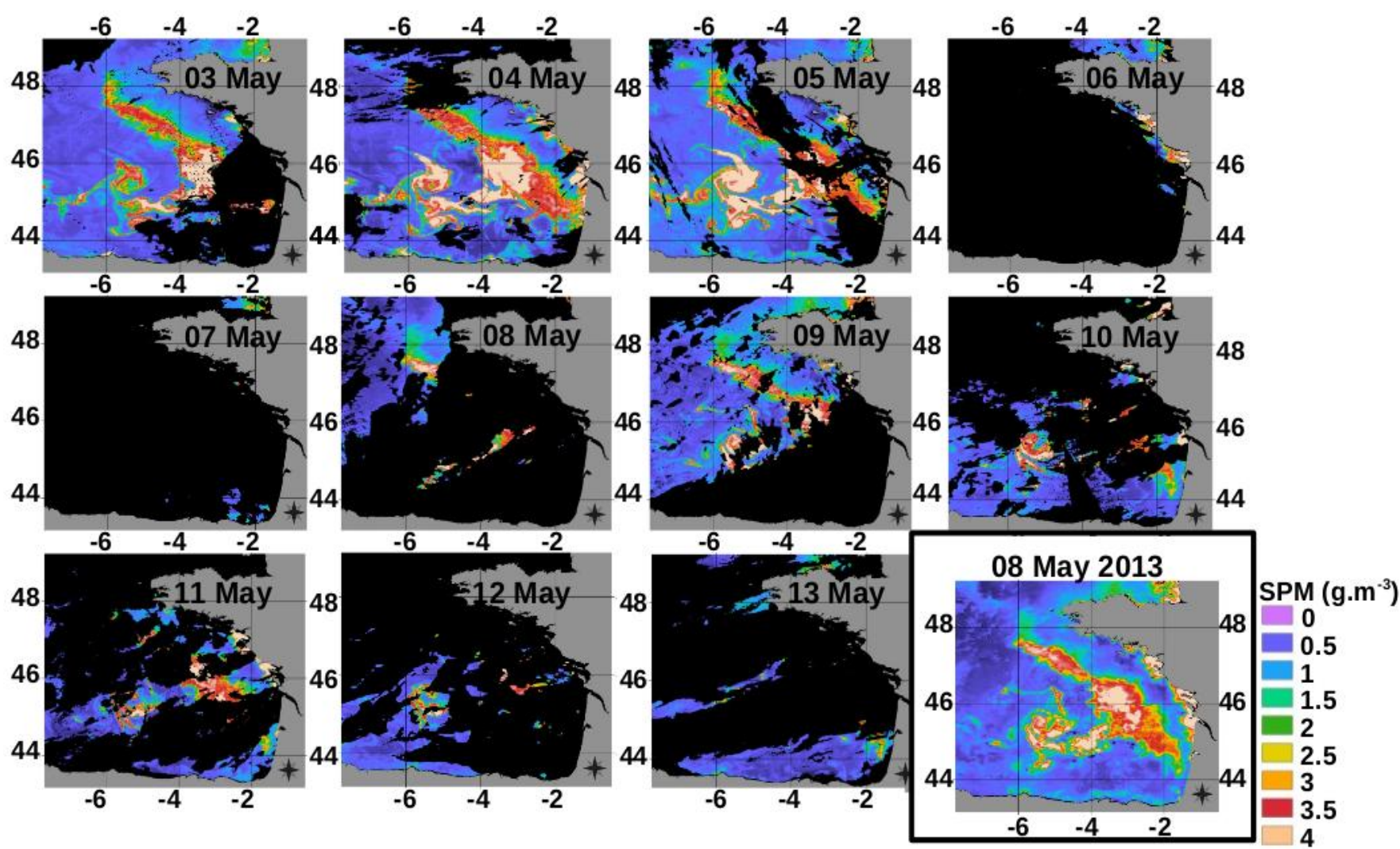

Fig. 3. The 11 daily satellite SPM images between May $3^{\text {rd }}$ and $13^{\text {th }}$ and the interpolated image of May $8^{\text {th }}, 2013$ (bottom right panel).

\subsubsection{Interannual variability of SPM and Chl-a between 2012 and 2015}

The variability of the coccolithophore blooms was investigated using daily SPM images, as shown on Fig. 4. For each year, 3 phases (onset, peak, and decay) in the development of the bloom were identified. A coccolithophore bloom was visible in 2012 in the northern part of the Bay of Biscay north of $46^{\circ} \mathrm{N}$ along the shelf-break, starting on May $1^{\text {st }}$ (Fig. 4a), with a maximum on May $10^{\text {th }}$ (Fig. 4b), declining May 20 ${ }^{\text {th }}$ (Fig. 4c), and decaying around May 25 ${ }^{\text {th }} 2013$ showed the longest occurring bloom as well as the largest extent (between $44^{\circ} \mathrm{N}$ and $48^{\circ} \mathrm{N}$ ). It started on April $15^{\text {th }}$ (Fig. 4d), and reached its maximum on May $1^{\text {st }}, 2013$. The end of the bloom occurred on May $30^{\text {th }}$, 2013 (Fig. 4f). There was no SPM signal in the spring of 2014 as shown on the interpolated SPM images (Fig. 4g-i). The bloom in 2015 started earlier than the other years, with a limited extent 
when compared to 2012 and 2013 (Fig. 4j). It was observed to occur between May $1^{\text {st }}$ and $20^{\text {th }}$ in the north, between $47^{\circ} \mathrm{N}$ and $48^{\circ} \mathrm{N}$ (Fig. $4 \mathrm{k}$ to 1 ).

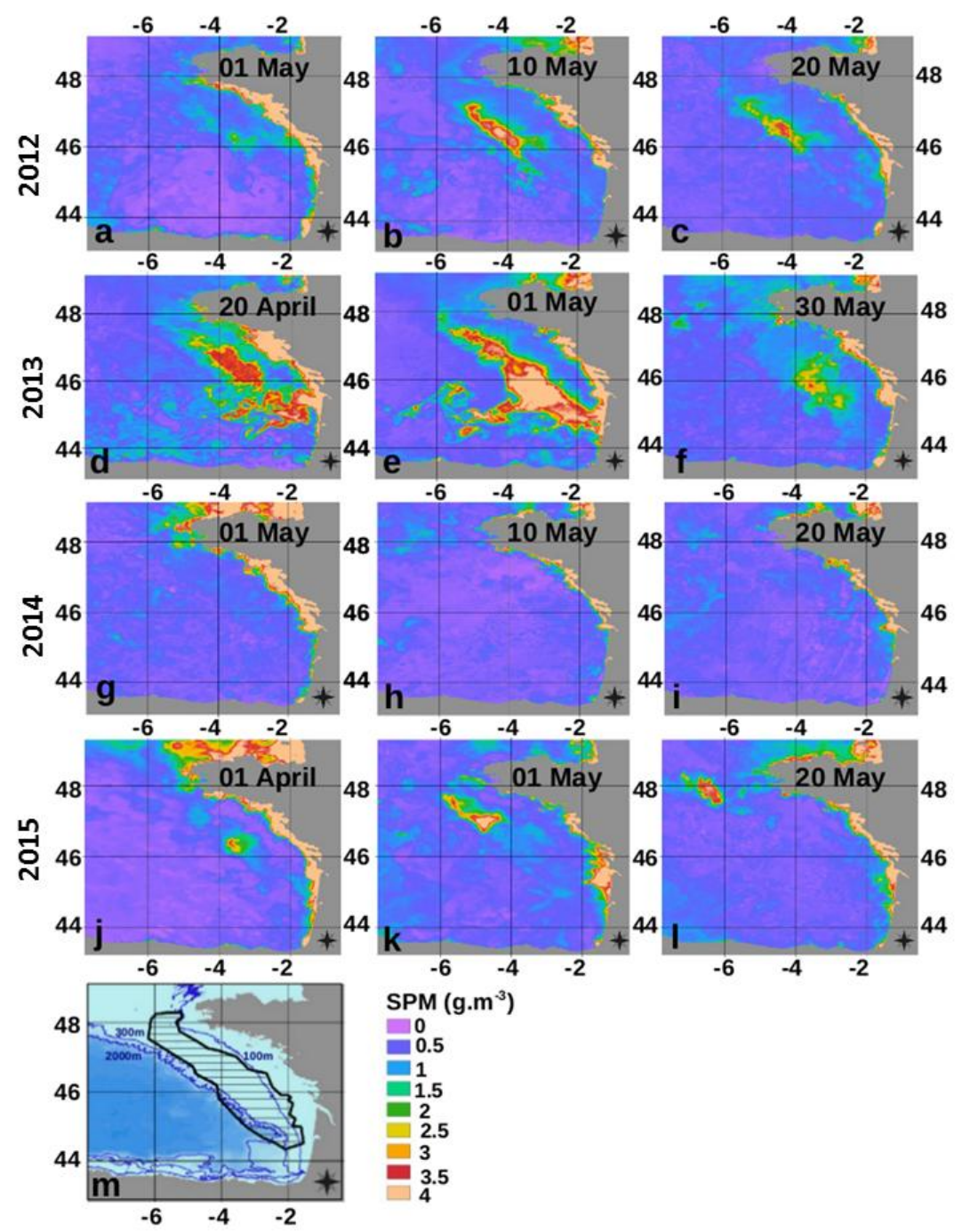

Fig. 4. SPM daily interpolated images at the onset, maximum and decline of the bloom. (a-c) 2012, (d-f) 2013, (g-i) 2014, (j-1) 2015, (m) the core Coccolith area (black line) selected.

From the SPM images spanning 2012 and 2015, a core coccolith area can be defined around the margin of the eastern shelf of the Bay of Biscay where coccolithophore blooms occur and where resuspension of sediment in the surface layer and transport of mineral particles by river plumes are marginal in May. For purposes of comparisons between satellite products and PELGAS observations, only in-situ profiles located in the core coccolith area were considered (Fig. $4 \mathrm{~m}$ ). 
Time-series of averaged satellite-derived Chl-a (OC5 algorithm) and SPM on the core coccolith area were calculated from January 2012 to December 2015 (Fig. 5). The SPM time-series shows two peaks every year, except in 2014, with a winter peak corresponding to resuspension of mineral SPM and a spring peak corresponding most probably to calcifying phytoplankton (as observed on Fig. 4). 2014 is particularly unusual: a strong SPM signal is observed in February 2014, with a maximum of $3.87 \mathrm{~g} . \mathrm{m}^{-3}$, and nothing is depicted in spring when coccolithophores are expected. This winter peak in SPM has been previously observed and explained by the resuspension due to waves generated by strong storms during the 2013/2014 winter (Gohin et al, 2015). This exceptionally windy winter ended suddenly at the beginning of March and was followed by a cyclonic and sunny period in mid-March that favoured the development of strong phytoplankton blooms. The second SPM peak, due to coccolithophores, occurs on May $8^{\text {th }}$ in $2012\left(1.33\right.$ g.m $\left.\mathrm{m}^{-3}\right)$, May $6^{\text {th }}$ in 2013 (2.89 g.m $\left.{ }^{-3}\right)$ and earlier in 2015, on April $23^{\text {rd }}\left(1.45\right.$ g.m $\left.{ }^{-3}\right)$.

The time-series of Chl-a (blue) shows moderately high level of chlorophyll for semi-coastal waters (Fig. 5). However, a narrow maximum blue peak is observed on March $30^{\text {th }}$, 2012 (3.26 mg.m ${ }^{-3}$, Fig. 5). It corresponds to a very strong and large bloom observed in the Bay of Biscay, probably diatoms as in March 2000 (Gohin et al., 2003). In spring, the peak of Chl-a occurs earlier than the peak of SPM with a delay of several days between the 2 peaks, 38 days for 2012, 16 days in 2013 and 7 days in 2015. Following our procedure based on the temporal succession of non-algal SPM and Chl-a, coccoliths are easily depicted in the vicinity of the shelf break. They are characterised in spring by their high level of non-algal SPM and their relatively low Chl-a concentration, which discards frustules of diatoms as source of SPM. 


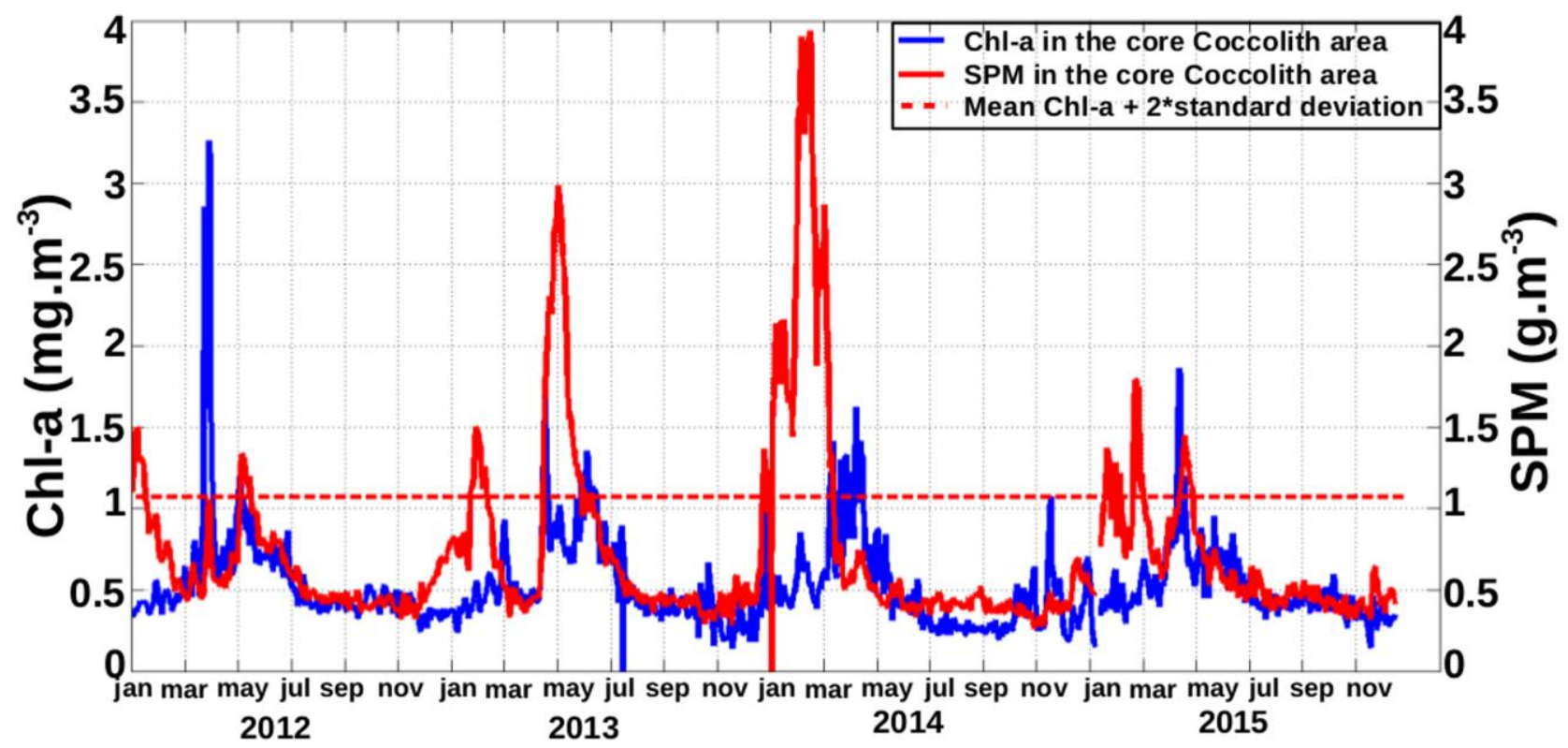

Fig. 5.

Time series of SPM (red line) and Chl-a (blue line) between 2012 and 2015 over the core coccolith area, and the mean $+2 *$ standard deviations of the Chl-a time-series $\left(1.07 \mathrm{mg} . \mathrm{m}^{-3}\right.$, in dashed red line).

\subsection{Turbidity and fluorescence profiles in May (2012-2015)}

Representative stations of the PELGAS surveys have been selected to investigate the state of the mixed surface layer in the presence or absence of coccolithophores on satellite images. Four stations at bloom locations were selected between May $17^{\text {th }}$ and $19^{\text {th }}, 2012$ (Fig. 6a). A second transect of 5 stations across the continental shelf is also considered as it corresponds to a location where the strongest coccolithophore bloom occurred, between May $7^{\text {th }}$ and $8^{\text {th }}, 2013$ (Fig. 6b). Insitu data are also available on this transect in 2014 around the same date, between May $6^{\text {th }}$ and $9^{\text {th }}$, 2014 (Fig. 6c) and for the year 2015 between May 11 ${ }^{\text {th }}$ and $13^{\text {th }}, 2015$ (Fig. 6d). Two stations inside an observed small coccolithophore bloom are also taken into account in 2015 in the northern part of the bay, at points 6 and 7 on May 29 ${ }^{\text {th }}, 2015$ (Fig. 6d).

The turbidity profiles at the stations of the transects are shown on Fig. 6e-h. The profiles from the stations inside the blooms, in 2012, 2013 and from the two northern stations in 2015, show 12 
similarities: the turbidity is higher than 0.6 NTU in the surface layer, to a depth that depends on the position of the station inside the area of the coccolithophore bloom. In 2012, the turbidity profiles from the surface to depth of $35-40 \mathrm{~m}$ for stations 1,3 and 4 remain close to $0.7 \mathrm{NTU}$, before decreasing to a value of 0.3 . The profile of station 2 in 2012, in the middle of the bloom, shows an homogeneous and higher turbidity around 1 NTU from the surface to a depth of $60 \mathrm{~m}$. The turbidity profiles from the other stations inside the blooms have the same shape, as in 2013 for station 3 in the middle of the bloom where the turbidity remains higher than 1 NTU from the surface to $80 \mathrm{~m}$ depth. The profiles 1 and 2 of the same transect in 2013 show also a maximum sub-surface peak at $21 \mathrm{~m}$ depth (1.7 NTU) and $18 \mathrm{~m}$ depth (2.9 NTU), respectively. Conversely, no bloom was observed during 2014 in the Bay of Biscay, and the turbidity profiles in 2014 from the same transect remain homogeneous with values in the surface layer below 0.5 NTU (Fig. 6g). The turbidity profiles from the same transect in 2015 (profiles 1 to 5 on Fig. 6h) where no bloom was observed show also low values, below 0.6 NTU with homogeneous profiles. In 2015, only the two profiles in the northern Bay of Biscay, stations 6 and 7, show turbidity levels higher than 0.6 NTU. The maximum turbidity values along the transect in the core coccolith area in the coccolithophore bloom for May 7-8, 2013 are between 3 and 6.6, much higher than for May 6-9, 2014, when coccolithophores were absent; this highlights the optical response of turbidity in case of coccolithophore blooms. The fluorescence profiles (except in 2014) for many of the stations are closely related to turbidity, meaning that coccolithophores cannot be easily dissociated from the photosynthetically-active phytoplankton that may coexist with them (Poulton et al., 2013). 


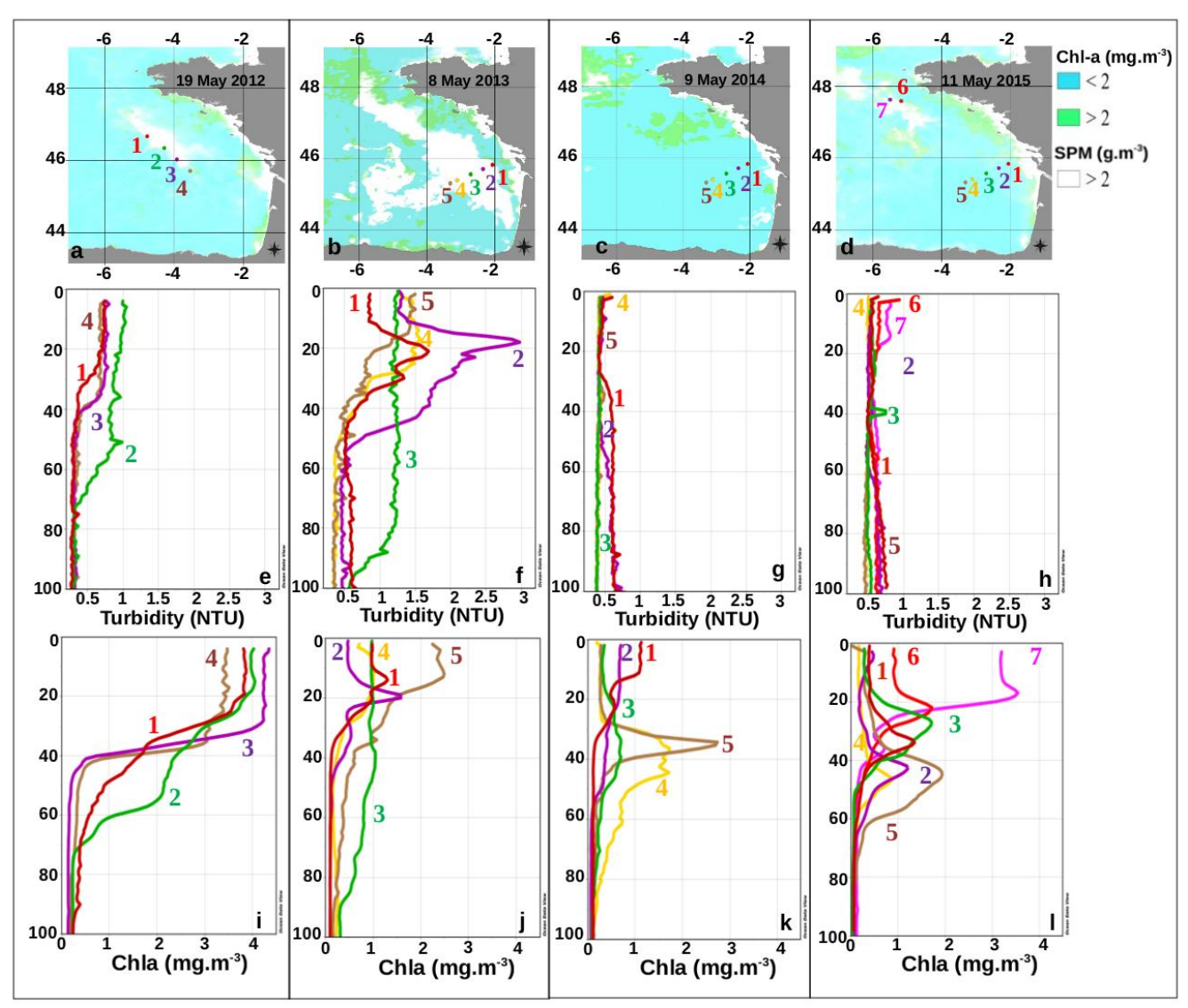

Fig. 6. In situ data along PELGAS transects on: a) May 17-19, 2012, b) May 7-8, 2013, c) May 69, 2014, d) May 11-13, 2015) with e, f, g, h) Turbidity profiles in NTU and i, j, k, l) Fluorescence profiles in $\mathrm{mg} \cdot \mathrm{m}^{-3}$.

\subsection{Comparison between satellite SPM and in situ turbidity, SPM and PIM}

Fig. 7a shows the total SPM retrieved from marine reflectance using formula (1) versus the in-situ turbidity in the core coccolith area in 2013. In 2013, when strong coccolithophore blooms were observed, the satellite-derived SPM appears to be as well related to in-situ turbidity (Fig. 7a) than in-situ SPM to turbidity (Fig. 7b) despite the fact that the satellite SPM is interpolated over several days whilst in-situ measurements were collected concomitantly. Fig. 7c shows the strong relationship between in-situ PIM and SPM inside the core coccolith. In this case, SPM was mainly derived from mineral source (PIM). Fig. 7d shows the same parameters as Fig. 7a and 7b, but in 2014. In 2014, low turbidity (close to $0.5 \mathrm{NTU}$ ) corresponds to low satellite-derived SPM (<1 g.m $\mathrm{m}^{-3}$ in blue points). However, in situ SPM remains relatively high (between 0.5 and $3.2 \mathrm{~g} . \mathrm{m}^{-3}$ in red 
dots). If turbidity is effectively low in 2014, the variability of the in-situ SPM observed on Fig. 7d is almost pure noise around a mean value as high as about $1.5 \mathrm{~g} . \mathrm{m}^{-3}$. In contrast to in-situ SPM, satellite SPM is consistent with the low level of turbidity observed in 2014. These results corroborate the good relationship observed between satellite-derived SPM and in-situ turbidity at the Liverpool buoy in the Irish Sea (Jafar-Sidik et al., 2017).
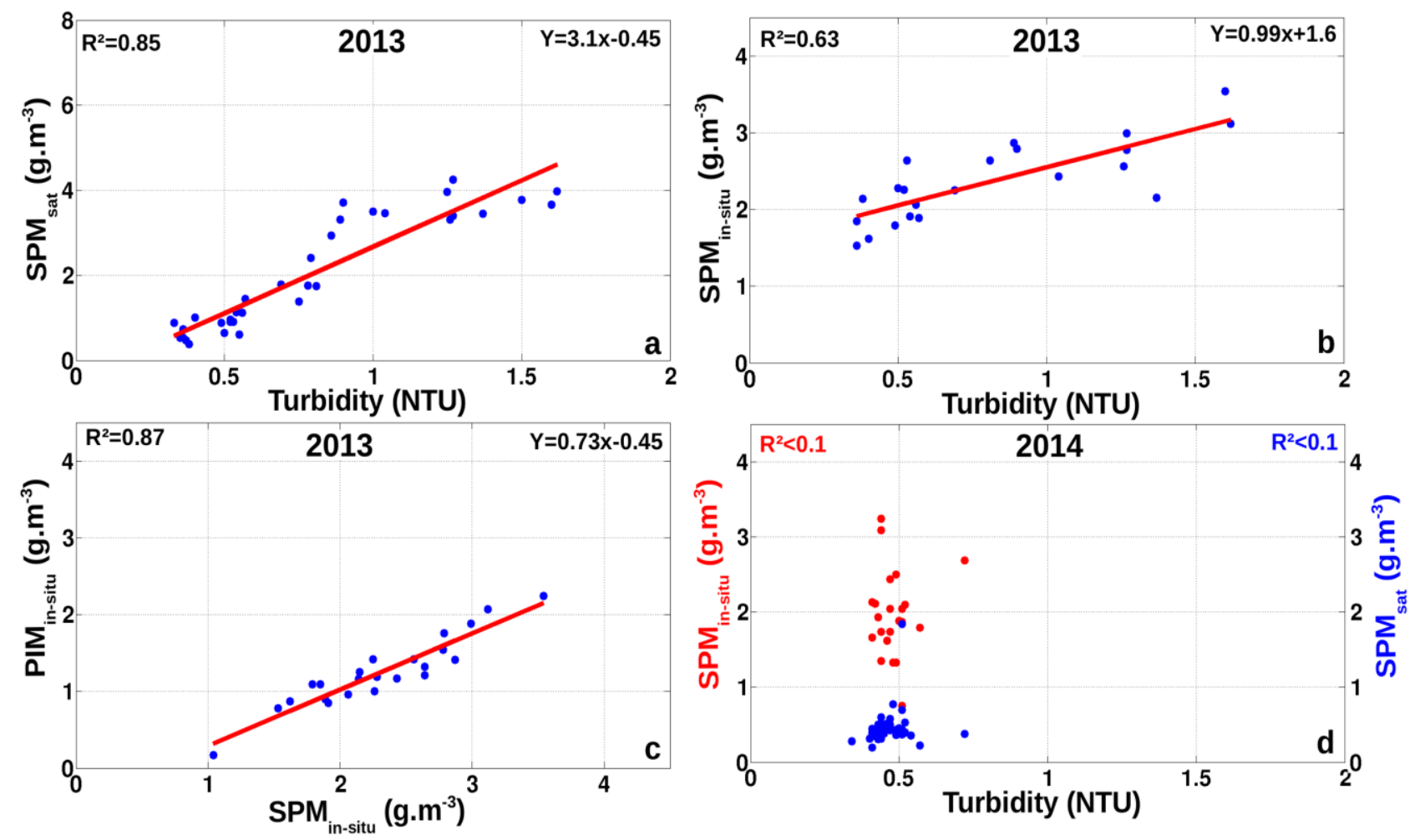

Fig. 7. Comparisons, in the core coccolith area, between satellite SPM, in-situ SPM, in-situ PIM and turbidity at surface. a) Satellite SPM versus turbidity in 2013; b) in-situ SPM versus turbidity in 2013; c) in-situ PIM versus in-situ SPM in 2013; d) Satellite (blue points) and in-situ (red points) SPM versus turbidity in 2014.

\subsection{Stratification of the water column}

\subsubsection{Density, temperature and salinity profiles}

The mean profiles of density, temperature and salinity from the PELGAS stations located within the coccolithophore blooms and those in the core coccolith area for each year are shown on Fig. 8a15 
c. The mean surface density, temperature and salinity in the core coccolith area are shown in Table 1. A lower density (average in Table. 1 and along the profile in Fig. 8) was observed in the coccolith-poor year, 2014, over the core coccolith area whereas the maximal averaged densities in the core coccolith area were higher in 2012 and 2013 (Table 1).

The temperature profiles reached the highest values for the core coccolith area in 2014 and 2015 within a $35 \mathrm{~m}$ depth layer for 2015, and $52 \mathrm{~m}$ in 2014 (Fig.8). Conversely, the mean surface temperatures were minimal in 2012 and 2013 in the core coccolith area. In that area, the maximum Sea Surface Temperature (SST) value in $2014\left(14.82^{\circ} \mathrm{C}\right.$, in Table 1) was higher than in 2012, 2013 and 2015 (Table 1). The averaged surface temperature for the stations inside the coccolithophore bloom was minimal in 2012 at the surface and remained below $14^{\circ} \mathrm{C}$ for the 2 coccolith-rich years of $2012\left(13.45^{\circ} \mathrm{C}\right.$, in Fig. 8 b) and $2013\left(13.96^{\circ} \mathrm{C}\right)$. The results from the profiles of Fig. 8 show that coccolithophores flourished, within our core coccolith area, in the less stratified and more dense waters. From year to year, this result can be extended and generalized to the whole core coccolith area: the colder and the denser the waters in May, the more likely coccolithophore blooms occur.
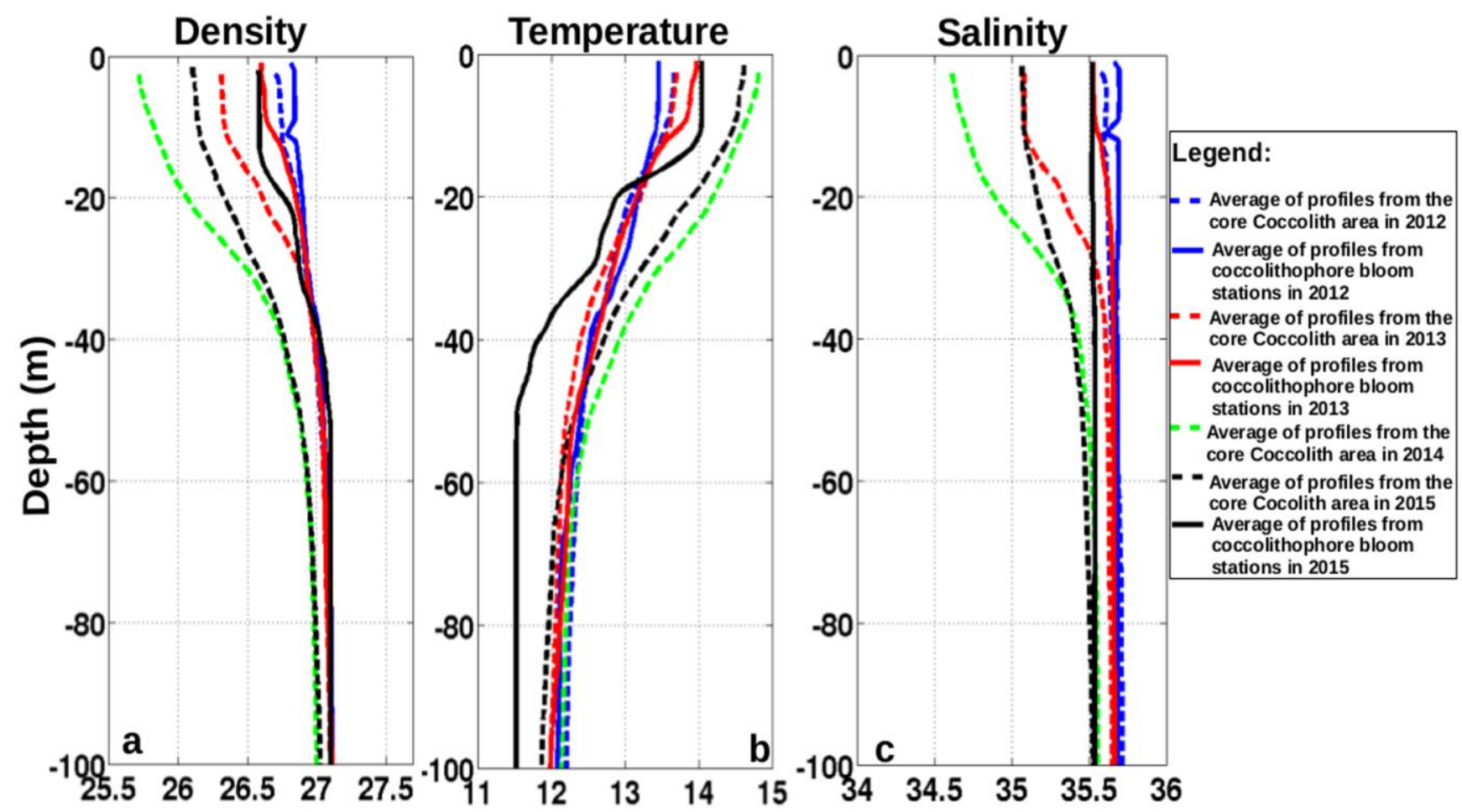

Fig. 8. Yearly averages of in-situ a) density (sigma-t), b) temperature $\left({ }^{\circ} \mathrm{C}\right)$, and c) salinity (psu) profiles. PELGAS stations in the core coccolith area. 
Table 1. Yearly averages of satellite-derived SPM (g.m $\left.\mathrm{m}^{-3}\right)$, in-situ surface turbidity (NTU), in-situ SPM $\left(\right.$ g. $\left.\mathrm{m}^{-3}\right)$, in situ PIM $\left(\mathrm{g} . \mathrm{m}^{-3}\right)$, surface in-situ Chl-a $\left(\mathrm{mg} \cdot \mathrm{m}^{-3}\right)$, nutrients $(\mu \mathrm{M})$, in-situ $\mathrm{SST}\left({ }^{\circ} \mathrm{C}\right)$, in-situ salinity (psu) and density (sigma-t) from stations in the core coccolith area between 2012 and 2015 .

\begin{tabular}{|c|c|c|c|c|}
\hline & 2012 & 2013 & 2014 & 2015 \\
\hline SPM g.m ${ }^{-3}$ (satellite) & $0.98 \pm 0.02$ & $2.03 \pm 0.23$ & $0.47 \pm 0.03$ & $0.52 \pm 0.02$ \\
\hline Turbidity NTU (surface) & $0.48 \pm 0.01$ & $0.79 \pm 0.07$ & $0.46 \pm 0.01$ & $0.57 \pm 0.01$ \\
\hline SPM g.m ${ }^{-3}$ (surface) & $1.90 \pm 0.11$ & $2.37 \pm 0.13$ & $1.90 \pm 0.11$ & $1.02 \pm 0.10$ \\
\hline PIM g.m ${ }^{-3}$ (surface) & $0.86 \pm 0.05$ & $1.29 \pm 0.10$ & $1.02 \pm 0.09$ & $0.45 \pm 0.12$ \\
\hline Chl-a mg.m ${ }^{-3}$ (surface) & $0.82 \pm 0.09$ & $0.64 \pm 0.07$ & $0.49 \pm 0.08$ & $0.45 \pm 0.05$ \\
\hline Si $\mu M$ (surface) & $1.30 \pm 0.15$ & $1.20 \pm 0.20$ & $0.67 \pm 0.14$ & l \\
\hline $\mathrm{NO}_{3}+\mathrm{NO}^{2} \mu \mathrm{M}$ (surface) & $1.68 \pm 1.32$ & $1.27 \pm 0.45$ & $0.84 \pm 0.28$ & l \\
\hline $\mathrm{PO}_{4} \boldsymbol{\mu M}$ (surface) & $0.14 \pm 0.02$ & $0.01 \pm 0.007$ & $0.002 \pm 0.002$ & l \\
\hline $\operatorname{SST}^{\circ} \mathrm{C}$ & $13.69 \pm 0.01$ & $13.70 \pm 0.02$ & $14.82 \pm 0.02$ & $14.62 \pm 0.02$ \\
\hline Salinity psu (surface) & $35.55 \pm 0.01$ & $35.07 \pm 0.02$ & $34.61 \pm 0.02$ & $35.06 \pm 0.01$ \\
\hline Density sigma-t (surface) & $26.68 \pm 0.04$ & $26.31 \pm 0.91$ & $25.71 \pm 0.09$ & $26.1 \pm 0.08$ \\
\hline
\end{tabular}

\subsubsection{Stratification index}

Fig. 9 shows low stratification indices in 2012 and 2013 and high indices in 2014 (Fig. 9c). The same trend was observed for the mean index averaged over our reference transects (excluding the small northern transect in 2015), as the maximum values are reached in 2014 and 2015 (Table 2). As for the core coccolith area, the lowest index values averaged over the transects were reached in 2012 and 2013, and the maximum in 2015 (1.27 \pm 0.2$)$.

The mean index in 2015 for the 2 stations located in a small coccolithophore bloom in the northern Bay of Biscay (Fig. 9d) was $0.53 \pm 0.02$, close to the mean index values in 2012 and 2013 over transects crossing a coccolithophore bloom. Among the 4 years, the averages of the stratification index were lower (indicative of a lower stratification) for the 2 coccolith-rich years 2012 and 2013, 
whereas the maximum average of the stratification index was reached in 2014 when coccolithophores were absent.

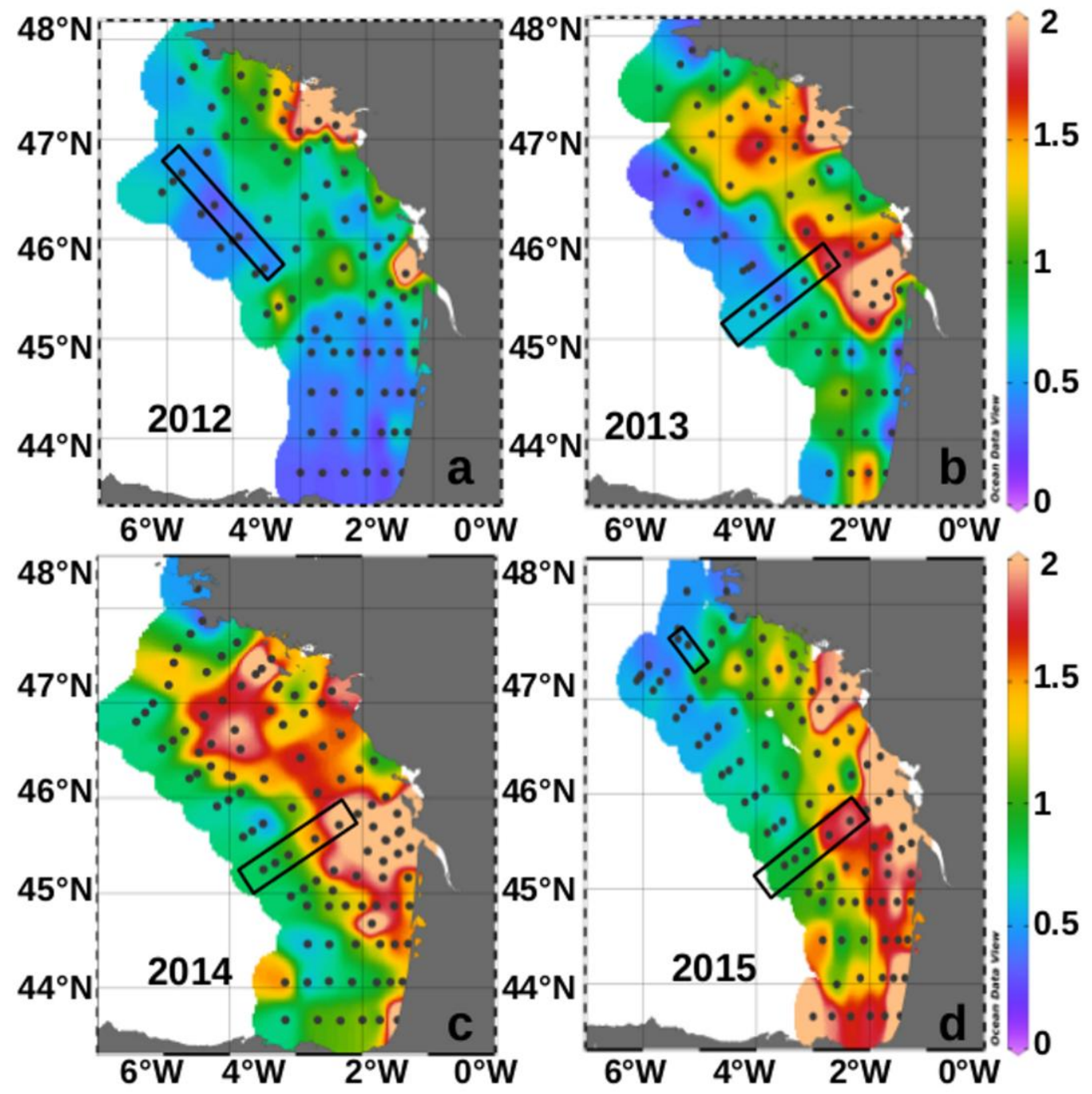

Fig.9 Index of stratification from the PELGAS stations in a) 2012, b) 2013, c) 2014 and d) 2015. Transects from Fig. 6 are indicated in black boxes.

Table 2. Averages of the stratification index in the core coccolith area and on the transects indicated 
on Fig. 9.

\begin{tabular}{|c|c|c|c|c|}
\hline & 2012 & 2013 & 2014 & 2015 \\
\hline Ind (core coccolith area) & $\begin{array}{c}0.61 \pm \\
0.05\end{array}$ & $0.88 \pm 0.1$ & $\begin{array}{c}1.28 \pm \\
0.1\end{array}$ & $\begin{array}{c}1.12 \pm \\
0.08\end{array}$ \\
\hline Ind (reference transects) & $0.35 \pm 0.03$ & $0.82 \pm 0.3$ & $\begin{array}{c}1.25 \pm \\
0.2\end{array}$ & $1.27 \pm 0.2$ \\
\hline
\end{tabular}

\subsubsection{Turbidity profiles and coccolithophore blooms in the water column}

To investigate quantitatively the variability of the blooms in the water column, turbidity is integrated between the surface and MLD and between MLD and the maximal slope of the density gradient (DGL). The average of the integrated turbidity calculated over the selected stations of Fig. 6 reached its maximal value in 2013 (TIT=68.12 NTU, in Table 3) whereas the value was halved in 2012 (34.88 NTU) and 4 times lower in 2015 (15.61 NTU). The integrated values show that in 2012 and 2015, the coccolithophore blooms are mainly observed in the surface layer delimited by the MLD, whereas the blooms occurred more in sub-surface in 2013 with a higher SPM concentration than the other years. The highest turbidity levels were maintained above the maximum density gradient (DGL) for all the years.

Table 3. Averages of integrated turbidity for coccolithophore bloom stations, integration from surface to the MLD (criterion of delta sigma=0.1) and from MLD to the density gradient layer (DGL) depth (criterion of maximum slope of density gradient).

\begin{tabular}{lccc}
\hline & $\mathbf{2 0 1 2}$ & $\mathbf{2 0 1 3}$ & $\mathbf{2 0 1 5}$ \\
\hline Total integrated turbidity (NTU) & 34.88 & 68.12 & 15.61 \\
$\begin{array}{l}\text { Integration of turbidity from surface to } \\
\text { MLD (NTU) }\end{array}$ & 30.21 & 25.43 & 10.14 \\
Integration of turbidity from MLD to DGL & 3.17 & 41.09 & 5.48 \\
(NTU) & 42.75 & 19.80 & 16.00 \\
MLD (m) & 50.25 & 56.00 & 43.50 \\
DGL (m) & & & \\
\hline
\end{tabular}

\subsection{PELGAS nutrients}


The yearly averages of nutrients $\left(\mathrm{Si}, \mathrm{NO}_{3}+\mathrm{NO}_{2}\right.$ and $\left.\mathrm{PO}_{4}\right)$ at the surface in the core coccolith area show that concentrations of phosphate and silicate remained low between 2012 and 2014 (Table 1). The highest contents of $\mathrm{NO}_{3}+\mathrm{NO}_{2}$ and $\mathrm{Si}$ in surface were reached in $2012(1.68 \pm 1.32 \mu \mathrm{M}$ $\left.\mathrm{NO}_{3}+\mathrm{NO}_{2}, 1.3 \pm 0.15 \mu \mathrm{M} \mathrm{Si}\right)$ and in $2013(1.27 \pm 0.45 \mu \mathrm{M} \mathrm{NO} 3,1.2 \pm 0.2 \mu \mathrm{M} \mathrm{Si})$. The stratified waters in 2014 were particularly depleted in all nutrients $\left(0.84 \pm 0.28 \mu \mathrm{M} \mathrm{NO}_{3}+\mathrm{NO}_{2} ; 0.67 \pm 0.14\right.$ $\left.\mu \mathrm{M} \mathrm{Si} ; 0.002 \pm 0.002 \mu \mathrm{M} \mathrm{PO}_{4}\right)$.

\section{Discussion}

\subsection{Turbidity during the PELGAS surveys}

In surface waters, coccospheres and detached coccoliths increase ambient turbidity which would otherwise be low in this area at this time of the year. Turbidity profiles also give information on the vertical structure of coccolithophore blooms. In 2012, 2013, and 2015 vertical profiles that exhibited high turbidity levels were also observed at surface on satellite images. This relation was confirmed by the absence of coccolithophore blooms observed from satellite imagery in 2014 when turbidity was insignificant throughout the water column.

As a further illustration of the opposite findings between 2013 and 2014, 2013 corresponded with the maximum yearly averages of satellite SPM $\left(2.03 \pm 0.23 \mathrm{~g} \cdot \mathrm{m}^{-3}\right)$, in-situ turbidity $(0.79 \pm 0.07$ NTU) and in-situ SPM $\left(2.37 \pm 0.13\right.$ g.m $\left.\mathrm{m}^{-3}\right)$, whereas 2014 , the coccolith-poor year, corresponded with the minimum value of satellite SPM $\left(0.47 \pm 0.03\right.$ g.m $\left.{ }^{-3}\right)$ and in-situ turbidity $(0.46 \pm 0.01$ NTU). Spatial changes in coccolithophore blooms from 2012 to 2015, with a coccolith-rich year in 2013 followed by a coccolith-poor year in 2014, are similar to observed changes from previous studies. High variability in bloom formation has also been observed in the North Atlantic between 1998 and 2005 (Raitsos et al, 2006). Morozov et al. (2013) have shown that the interannual variability of the coccolithophore blooms in the Bay of Biscay is different between the northern part and the central part. Blooms occur nearly every year in the northern part and irregularly in the central part. This is in agreement with the satellite and in-situ observations that prevailed during the PELGAS surveys: The bloom occurred in the northern part in 2012, 2013, and 2015 but without any central and southern component in 2014 and 2015. Moreover, 2014 appeared on the satellite 
imagery like a non-bloom year in the Bay of Biscay as well as in the Celtic Sea (from independent observations of our satellite imagery).

Turbidity profiles during coccolithophore blooms observed in the Bay of Biscay corresponded to vertical distributions shown to be common in many other oceanic regions. In our survey (2012 2015), we pointed out where and for how long the coccolithophore blooms lasted (between two weeks to more than a month). In order to estimate the total mass of the blooms, it is necessary to know their vertical distribution, which can not be assessed from satellite imagery. The coccolithinduced turbidity was high in the first forty meters at station 1 in 2012, station 5 in 2013 and stations 6 and 7 in 2015 (Fig. 6). However, coccoliths are also detected as deep as $90 \mathrm{~m}$ in 2013 (Fig. 6f) and have even been reported down to $150 \mathrm{~m}$ depth in March 2004 (Schiebel et al., 2011). The strong year to year variability of the turbidity profiles observed in this study suggests that monitoring coccolithophore blooms by satellite data alone would bias their total biomass.

\subsection{Impact of stratification on coccolithophore blooms}

Temperature and salinity are generally considered as factors conditioning the development of coccolithophore blooms (Paasche, 2001; Tyrell and Merico, 2004). The optimal temperatures for coccolithophore blooms are considered between 2 to $15^{\circ} \mathrm{C}$ by Holligan et al. (1993b), Raitsos et al. (2006), Merico et al. (2004), and between 3 and $15^{\circ} \mathrm{C}$ in upper ocean by Iglesias-Rodriguez (2002). In this study, minimum SST values occurred in $2012\left(13.6^{\circ} \mathrm{C}\right)$ and $2013\left(13.8^{\circ} \mathrm{C}\right)$ and maximum SST values were reached in 2014 and $2015\left(14.5^{\circ} \mathrm{C}\right.$ and $14.6^{\circ} \mathrm{C}$ respectively; Fig. $8 \mathrm{~b}$ and $\left.8 \mathrm{c}\right)$.

Stratification has been described as an important parameter conditioning the development of coccolithophores (Tyrell and Merico, 2004). Density profiles (2012-2015) suggest that the years with a higher stratification are not favourable for coccolithophore blooms (Fig. 9 and Table 2). This can also be seen for 2012 and 2013 (Fig. 8a), where the surface density averages reach the maximum for coccolithophore bloom stations and for the core coccolith area, whereas the minimum density average is reached in 2014 when no coccolithophore bloom occurred. Except for 2014, the averages of density profiles from stations in coccolithophore blooms (solid lines, Fig. 8a) are higher than the averages of total density profiles from the core coccolith area (dashed lines, Fig. 
8a).

Although coccolithophore blooms have been shown to take place in shallow mixed layer depths ( $<20 \mathrm{~m}$, Raitsos et al, 2006) and are thought to be favoured by stratification during the last stage of spring phytoplankton blooms (Holligan et al., 1983, 1993a; Balch et al., 1992; Kristiansen et al., 1994; Van der Wal et al., 1995; Rees et al., 2002), other important physical and environmental conditions have also been reported to influence their distribution. For example, in the Equatorial Western-central Pacific, E.huxleyi was abundant below the thermocline in a well-stratified region (Hagino et al., 2000) of temperate mixed-layer water. In the North Atlantic, at $47^{\circ} \mathrm{N}$, in conditions of high turbulence during the spring bloom, E.huxleyi flourished during an early stage of the phytoplankton succession when euphotic conditions allowed new production at deep mixing, low temperatures, and high nutrient concentrations (Schiebel et al., 2011). Two distinct environmental conditions were also reported (Giraudeau et al., 2016) over the Barents Sea shelf and slope, one in a well-stratified mixed-layer and the other in a well mixed cool layer close to the Polar front. In the Bay of Biscay from mid-April to the end of May, coccolithophores preferentially thrive on the margin of the continental shelf in less stratified areas. It is not surprising that from year to year their abundance is greater when the area of these mixed waters increases and extends toward the open ocean and over the continental shelf as in 2013.

Other hydrological parameters could impact the presence (2013) or absence (2014) of coccoliths. Coccolithophore are known to develop preferentially after the diatom-dominated spring bloom when silicate and phosphate are at limiting levels for further diatom growth (Balch et al., 2014) Phosphates could be therefore more limiting than nitrates (Townsend et al. 1994), with phosphate concentration measured from 0.02 to $0.16 \mu \mathrm{M}$ in bloom stations versus 0.21 to $0.49 \mu \mathrm{M}$ at nonbloom stations. However, it is also suggested that low concentration of phosphates is not an absolute requirement for the blooms (Tyrell and Merico, 2004). The bloom situations observed in this study is similar to that found during spring-summer in the Bay of Biscay (Loyer et al., 2006) when silicates and phosphates were depleted after the diatom-dominated spring bloom. The lowest concentrations of nutrients reached in 2014 in our study could be the result of an earlier and longer phytoplankton bloom. 


\subsection{Non-algal SPM and coccolith abundance}

No data were available during the period of this study (2012-2015) to quantify the coccoliths calcite mass nor to identify the coccolithophore taxa. What we have observed though is a good relationship between satellite-derived SPM (summing algal and non-algal SPM, the latter being the dominant component on the coccolithophore blooms) and turbidity, which has been observed at other locations and on other suspended materials (Jafar-Sidik et al., 2017). However, we observe an overestimation of SPM by satellite algorithm. This was expected as this semi-analytical algorithm is based on the hypothesis that all particles in the surface waters have the same massspecific backscattering coefficient. In a coastal site, as the Liverpool mooring in the Irish Sea, the algorithm underestimates non-algal SPM in summer (Jafar-Sidik et al., 2017). This is explained by the presence of large particles aggregated in flocs, likely to have a lower backscattering coefficient by unity of mass. Conversely, non-algal SPM due to coccoliths could be overestimated by the algorithm because the small coccoliths (in the order of 3-5 $\mu \mathrm{m}$ ) could be better light scatterers than the non-algal particles commonly encountered on the continental shelf. Non-algal SPM is indeed about 5 times higher than the calcite mass derived from the NASA team algorithm (not shown). The situation during May in the Bay of Biscay could be even more complex as many coexisting coccolithophore taxa may have composed the blooms. Fig. 9 shows the dominant species observed

by Scanning Electron Microscopy from samples collected on May 21 ${ }^{\text {st }}, 2016$ and May 22 $2^{\text {nd }}, 2017$, west of Brittany. In the 2016 bloom, of moderate concentration, 18 taxa belonging to 5 genera were observed (Perrot, 2017). First analyses show good relationships between the number of detached coccoliths and coccospheres and turbidity (data non shown) but these relationships are speciesdependent making the quantification of the calcite mass within the coccolithophore blooms even more difficult. At the end of May 2017 (Fig. 9b), the SPM concentration and the coccolithophore concentration were higher than in 2016. It is also worth noting that Emiliania Huxleyi was largely dominant in 2017 amongst coccolithophore taxa in the centre of the bloom, corroborating the role of this species as a major contributor to coccolithophore blooming in the northern Atlantic. 


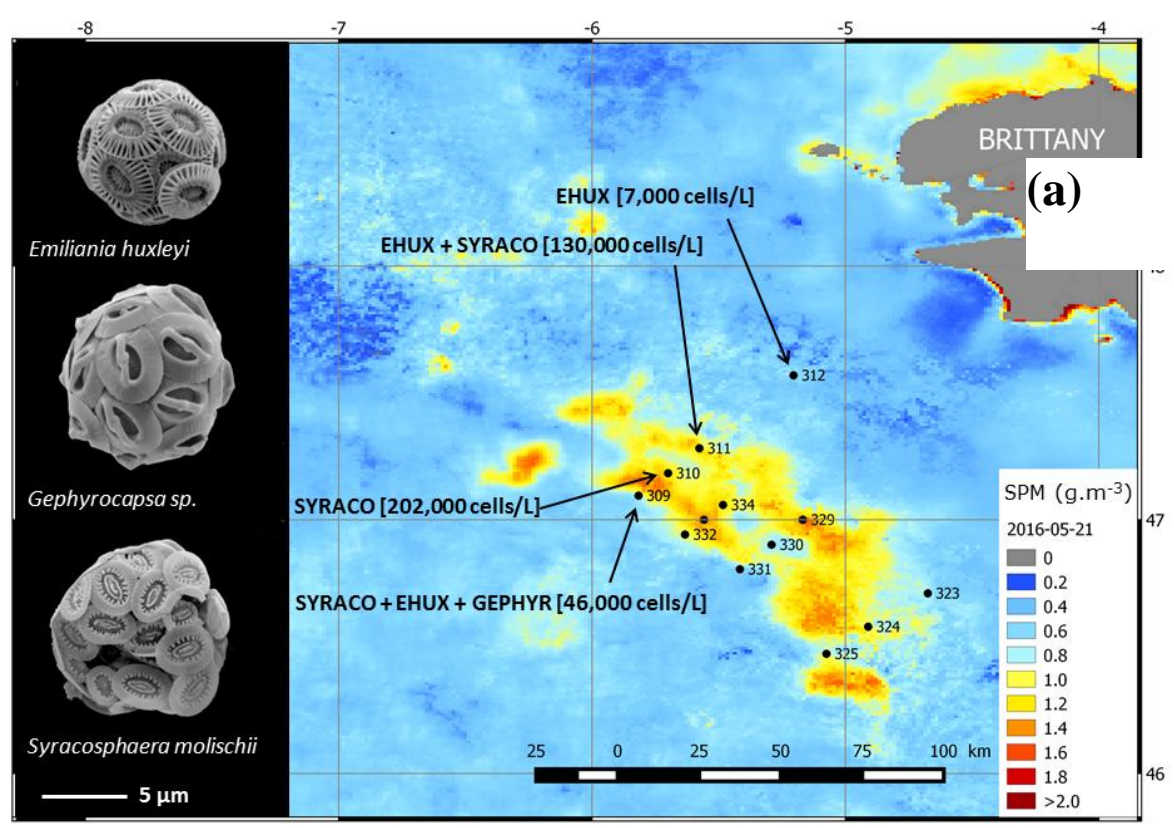

EHUX $=$ Emiliania huxleyi $\quad$ GEPHYR $=$ Gephyrocapsa sp. SYRACO $=$ Syracosphaera molischii

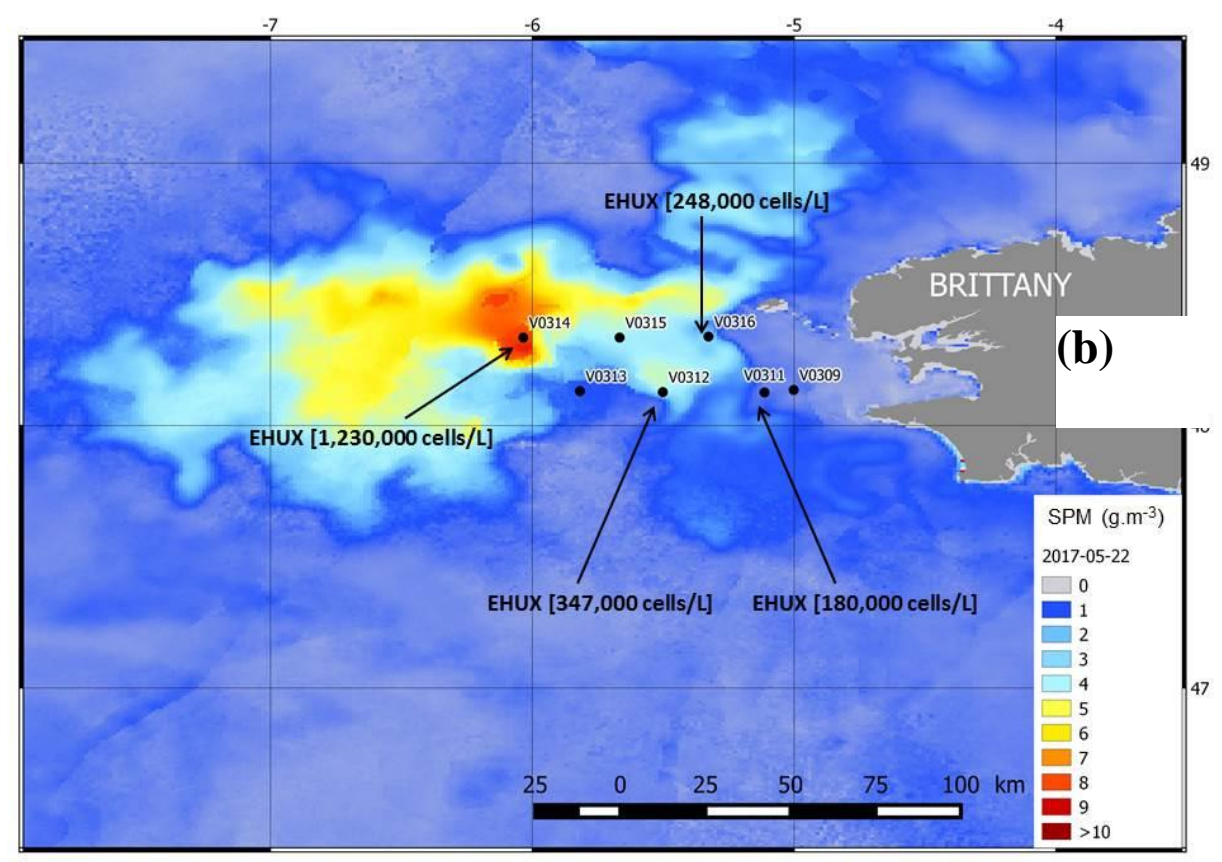

Fig. 9. The dominant coccolithophore taxa and cell densities observed at the end of the PELGAS surveys in 2016 and 2017

(a) non-algal SPM image of May $21^{\text {st }}$, 2016. (b) non-algal SPM image of May $22^{\mathrm{d},} 2017$.

\subsection{Is the presence of coccolithophores useful for rapidly characterising the biological}




\section{environment prevailing before the PELGAS surveys?}

Because of our observation that the onset of coccolithophore blooms is enhanced in unstratified waters, coccolithophore blooms (area and intensity) could be used as an indicator of mixed waters. We should also expect an effect of the hydrological conditions on the upper trophic level in the Bay of Biscay at the time of the PELGAS survey. In 2013 mean abundance of spring mesozooplanktonic community was $2508 \pm 1855$ ind. $\mathrm{m}^{-3}$ with $66.6 \%$ copepods, and in 2014,2355 \pm 3908 ind. $\mathrm{m}^{-3}$ with $76.5 \%$ copepods. The high standard deviation observed in 2014 indicated a strong spatial heterogeneity compared to spring 2013, showing a stronger coastal to shelf break gradient in abundance in spring 2014 (data not shown; see Dessier et al, 2017). This observation suggests that the mesozooplankton community in 2014 was a more "mature" community than in 2013. As shown by Dupuy et al. (2011), a more "mature" situation leads to an increase of the gradient in mesozooplanktonic abundance from the coast to the shelf break. This is consistent with the onset of the spring bloom that occurred about a month earlier in the coccolith-poor year in 2014, as shown in section 3.1, than in the coccolith-rich year of 2013.

\section{Conclusion}

A good agreement has been observed when coccolithophores thrive between satellite-derived SPM and surface turbidity during May in the Bay of Biscay. Moreover, the turbidity profiles confirm the representativeness of the surface observations provided from space. The turbidity and fluorescence profiles have also shown that the coccolithophores were active down to $60 \mathrm{~m}$ on the margin of the shelf break in poorly-stratified waters.

Over the shelf break of the Bay of Biscay and its vicinity, spatially and throughout the years, in contrast to the common consensus, coccolithophore blooms occur preferentially in less stratified waters (lower temperatures and higher salinity). The environmental differences observed in the stratification between the two coccolith-rich years (2012 and 2013) and the two coccolith-poor years (2014 and 2015) could also impact other components of the pelagic food web such as the mesozooplankton. In May, coccolith-poor years show a late-spring ecological situation with higher stratification, lower nutrient concentrations, and a more "mature" community of mesozooplankton, 
which is likely to have an influence on the growth of the larvae of small pelagic fishes targeted by the PELGAS surveys. Based on a degree-day approach, Huret et al. (2017) also evidenced a more mature ecosystem in 2015 and especially 2014, than in 2012 and 2013.

The good agreement between satellite SPM and turbidity for describing coccolithophore blooms suggests a more extensive use of turbidity data to monitor these blooms. To improve the quantification of calcite mass associated with coccolithophores we suggest a comparison between turbidity and the outputs of the Calcite NASA algorithm (Balch et al., 2005) taking into account coccolithophore species and the percentage of detached coccoliths. Pattern identification of coccolithophore blooms from space together with low-cost sampling schemes investigating the vertical distribution of the coccolithophore taxa in the deep maximum should further improve our ability to understand the role of coccolithophores in biogeochemical cycles. The PELGAS surveys provide an opportunity to build up such a scheme in the future.

\section{Acknowledgements}

The authors deeply thank Amos Winter for useful advices and for checking the final manuscript. Mesozooplankton data from PELGAS 2013 and 2014 provided by A. Dessier were obtained through a $\mathrm{PhD}$. grant from the Conseil Régional de Poitou-Charentes and the European project REPRODUCE (Era Net-Marifish, FP7). The authors thank particularly the NASA Goddard Space Flight Center for providing MODIS and VIIRS data. They are also very grateful to the mission chief of the Pelgas survey (Mathieu Doray) and to the crew of the THALASSA research vessel (Ifremer).

\section{References:}

1. Aminot , A, Kerouel, R., 2005. Hydrologie des parameters marins, Paramètres et analyses, Ifremer.

2. Balch, W. M., P. M. Holligan, and K. A. Kilpatrick, 1992. Calcification, photosynthesis and growth of bloom- forming coccolithophore, Emiliania huxleyi. Continental Shelf Research, 12, 
1353-1374, doi:10.1016/0278-4343(92) 90059-S.

3. Balch, W.M., Gordon, H.R., Bowler, B.C., Drapeau, D.T., Booth, E.S., 2005. Calcium carbonate measurements in the surface global ocean based on Moderate-Resolution Imaging Spectroradiometer data. Journal of Geophysical Research: Oceans 110, C07001, doi:10.1029/2004JC002560.

4. Balch, W. M., Drapeau, D. T., Bowler, B. C., Lyczkowski, E., Lubelczyk, L. C., Poulton, A. J., and Painter, S. C., 2014, Surface biological, chemical and optical properties of the Patagonian Shelf coccolithophore bloom, the brightest waters of the Great Calcite Belt: Limnology and Oceanography. 59 (5): 1715-1732.

5. Beaufort, L., Heussner, S., 1999. Coccolithophorids on the continental slope of the Bay of Biscay-production, transport and contribution to mass fluxes. Deep Sea Research II, 46, 21472174.

6. Beaufort, L., Couapel, M. J. J., Buchet, N. et al., 2008. Calcite production by Coccolithophores in the South East Pacific Ocean. Biogeosciences, 5, 1101 - 1117.

7. Boyd, P.W., Strzepek, R., Fu, F.X., Hutchins, D.A., 2010. Environmental control of open-ocean phytoplankton groups: now and in the future. Limnology and Oceanography, 55, 1353-1376.

8. Brown, Christopher W., et James A. Yoder, 1994. «Coccolithophorid Blooms in the Global Ocean. ». Journal of Geophysical Research: Oceans 99, n C4: 7467-82. doi:10.1029/93JC02156.

9. Charria, G., Lazure, P., Le Cann, B., Serpette, A., Reverdin, G., Louazel, S., Batifoulier, F., Dumas, F., Pichon, A., Morel, Y., 2013. Surface layer circulation derived from Lagrangian drifters in the Bay of Biscay. Journal of Marine Systems, XII International Symposium on Oceanography of the Bay of Biscay 109-110, Supplement, S60-S76. doi:10.1016/j.jmarsys.2011.09.015.

10. Costoya, X., deCastro, M., Gómez-Gesteira, M. and Santos, F., 2015. Changes in sea surface 27 
temperature seasonality in the Bay of Biscay over the last decades (1982-2014). Journal of Marine System, 150, 91-101.

11. de Boyer Montégut, C., J. Mignot, A. Lazar, and S. Cravatte, 2007. Control of salinity on the mixed layer depth in the world ocean: 1. General description. Journal of Geophysical Research, 112 , C06011, HYPERLINK "http://dx.doi.org/10.1029/2006JC003953"ㅁoi:10.1029/2006JC003953.

12. Dessier, A., 2015. Analyse du compartiment mésozooplanctonique et écologie alimentaire printanière de la sardine, Sardina pilchardus (Walbaum, 1782), et de l'anchois, Engraulis encrasicolus (Linné, 1758) adultes dans le Golfe de Gascogne. Interactions entre organismes. Université de La Rochelle. Français.<NNT : 2015LAROS036>.<tel-01373451>.

13. Dupuy, C., Talarmin, A., Hartmann, H.J., Delmas, D., Courties, C., Marquis, E., 2011. Community structure and grazing of the nano-microzooplankton on the continental shelf of the Bay of Biscay. Estuarine, Coastal and Shelf Science, 95, 1-13, doi:10.1016/j.ecss.2011.05.002.

14. Fritz, J.J., 1999. Carbon fixation and coccolith detachment in the coccolithophore Emiliania huxleyi in nitrate-limited cyclostats. Mar Biol 133, 509-518.

15. Fritz, J.J., Balch, W., 1996. A light-limited continuous culture study of Emiliania huxleyi: determination of coccolith detachment and its relevance to cell sinking. J. Exp. Mar. Biol. Ecol. 207, 127-147.

16. Giraudeau J., Hulot V., Hanquiez V., Devaux L., Howa H., Garlan T., 2016. A survey of the summer coccolithophore community in the western Barents Sea. Journal of Marine Systems, 158, 93-105, doi:10.1016/j.jmarsys.2016.02.012.

17. Gohin, F., Druon, J.N., Lampert, L., 2002. A five channel chlorophyll concentration algorithm applied to SeaWiFS data processed by SeaDAS in coastal waters. International Journal of Remote 
Sensing, 23, 1639-1661, doi:10.1080/01431160110071879.

18. Gohin, F., Lampert, .L, Guillaud, J.F., Herbland , A., Nezan, E., 2003. Satellite and in situ observations of a late winter phytoplankton bloom, in the northern Bay of Biscay. Continental Shelf Research, 23(11-13), 1117-1141. Publisher's official version : HYPERLINK "http://doi.org/10.1016/S0278-4343(03)00088-8"http://doi.org/10.1016/S0278-4343(03)00088-8 , Open Access version : HYPERLINK "http://archimer.ifremer.fr/doc/00000/463/"http://archimer.ifremer.fr/doc/00000/463/

19. Gohin, F., Loyer, S., Lunven, M., Labry, C., Froidefond, J.-M., Delmas, D., Huret, M., Herbland, A., 2005. Satellite-derived parameters for biological modelling in coastal waters: Illustration over the eastern continental shelf of the Bay of Biscay. Remote Sensing of Environment, 95, 29-46, doi:10.1016/j.rse.2004.11.007.

20. Gohin, F., Bryère, P., Griffiths, J.W., 2015. The exceptional surface turbidity of the North-West European shelf seas during the stormy 2013-2014 winter: Consequences for the initiation of the phytoplankton blooms? Journal of Marine Systems, 148, 70-85, doi:10.1016/j.jmarsys.2015.02.001.

21. Gordon, H., Boynton, G.C., Balch, W.M., Groom, S.B., Harbour, D.S., Smyth, T.J., 2001. Retrieval of coccolithophore calcite concentration from SeaWiFS imagery. Geophysical Research Letters, 28, 1587-1590.

22. Groom, S.B., Holligan, P.M., 1987. Remote sensing of coccolithophore blooms. Advances in Space Research, 7, 73-78, doi:10.1016/0273-1177(87)90166-9.

23. Guillaud, J.F., Aminot, A., Delmas, D., Gohin, F., Lunven, M., Labry, C., Herbland, A., 2008. Seasonal variation of riverine nutrient inputs in the northern Bay of Biscay (France), and patterns of marine phytoplankton response. J.Mar.Syst., 72, 309-319. 
24. Hagino, K., Okada, H., Matsuoka, H., 2000. Spatial dynamics of coccolithophore assemblages in the Equatorial Western-Central Pacific Ocean. Marine Micro-paleontology, 39, 53-72. http://dx.doi.org/10.1016/S0377-8398(00)00014-1.

25. Harlay, J., Borges, A.V., Van Der Zee, C., Delille, B., Godoi, R.H.M., Schiettecatte, L.-S., Roevros, N., Aerts, K., Lapernat, P.-E., Rebreanu, L., Groom, S., Daro, M.-H., Van Grieken, R., Chou, L., 2010. Biogeochemical study of a coccolithophore bloom in the northern Bay of Biscay (NE Atlantic Ocean) in June 2004. Progress in Oceanography, 86, 317-336, doi:10.1016/j.pocean.2010.04.029.

26. Holligan, P.M., Viollier, M., Harbour, D.S., Camus, P., Champagne-Philippe, M., 1983. Satellite and ship studies of coccolithophore production along a continental shelf edge. Nature, 304, 339342. doi:10.1038/304339a0.

27. „Holligan, P.M., Fernández, E., Aiken, J., Balch, W.M., Boyd, P., Burkill, P.H., Finch, M., Groom, S.B., Malin, G., Muller, K., Purdie, D.A., Robinson, C., Trees, C.C., Turner, S.M., van der Wal, P., 1993a. A biogeochemical study of the coccolithophore, Emiliania huxleyi, in the North Atlantic. Global Biogeochemical Cycles, 7, 879-900. doi:10.1029/93GB01731.

28. Holligan, P. M., Groom, S. B. and Harbour, D. S., 1993b. What controls the distribution of the coccolithophore, Emiliania huxleyi, in the North Sea? Fisheries Oceanography, 2, 175-183.

29. Hopkins, J., Henson, S. A., Painter, S.C., Tyrrell, T., Poulton, A.J., 2015. Phenological characteristics of global coccolithophore blooms, Global Biogeochem. Cycles,29, 239-253.

30. Huret, M., Bourriau, P., Doray, M., Gohin, F., Petitgas, P., Survey timing vs. ecosystem scheduling: degree-days to underpin observed variability with application to anchovy and sardine spawning in the Bay of Biscay, Progress in Oceanography, this issue, in press. Mais je ne vois pas ou il est cité, pas vérifié les autres !

31. Iglesias-Rodríguez, M. D., Brown, C. W., Doney, S. C. et al., 2002. Representing key 30 
phytoplankton functional groups in ocean carbon cycle models: Coccolithophores. Global Biogeochemical Cycles, 16,1100.

32. Jafar-Sidik, M., Gohin, F., Bowers, D., Howarth, J., Hull, T., 2017. The relationship between Suspended Particulate Matter and Turbidity at a mooring station in a coastal environment: consequences for satellite-derived products. Oceanologia, in press, HYPERLINK "http://doi.org/10.1016/j.oceano.2017.04.003" In _blankhttp://doi.org/10.1016/j.oceano.2017.04.003.

33. Jin, X., Liu, C., Poulton, A.J., Dai, M., Guo, X., 2016. Coccolithophore responses to environmental variability in the South China Sea: species composition and calcite content. Biogeosciences, 13, 4843-4861. doi:10.5194/bg-13-4843-2016.

34. Kristiansen, S., T. F. Thingstad, P. Van der Wal, T. Farbrot, and E. F. Skjoldal, 1994. An Emiliania huxleyi dominated subsurface bloom in Samnangerfjorden, western Norway. Importance of hydrography and nutrients, Sarsia, 79, 357-368.

35. Lampert, L., Queguiner, B., Labasque, T., Pichon, A., Lebreton, N., 2002. Spatial variability of phytoplankton composition and biomass on the eastern continental shelf of the Bay of Biscay (north-east Atlantic Ocean). Evidence for a bloom of Emiliania huxleyi (Prymnesiophyceae) in spring 1998. Continental Shelf Research, 22, 1225-1247.

36. Leblanc, K., Hare, C.E., Feng, Y., Berg, G.M., DiTullio, G.R., Neeley, A., Benner, I., Sprengel, C., Beck, A., Sanudo-Wilhelmy, S.A., Passow, U., Klinck, K., Rowe, J.M., Wilhelm, S.W., Brown, C.W., Hutchins, D.A., 2009. Distribution of calcifying and silicifying phytoplankton in relation to environmental and biogeochemical parameters during the late stages of the 2005 North East Atlantic Spring Bloom. Biogeosciences, 6, 2155-2179.

37. Lorenzen, C.J., 1967. Determination of Chlorophyll and Pheopigments: Spectrophotometric Equations. Limnology and Oceanography, 12, 343-346 
38. Loyer, S., Lampert, L., Menesguen, A., Cann, P. and Labasque, T., 2006. Seasonal evolution of the nutrient pattern on Biscay Bay continental shelf over the years 1999-2000. Scientia Marina, 70, $31-46$.

39. Merico, A., Tyrrell, T., Lessard, E.J., Oguz, T., Stabeno, P.J., Zeeman, S.I., Whitledge, T.E., 2004. Modelling phytoplankton succession on the Bering Sea shelf: role of climate influences and trophic interactions in generating Emiliania huxleyi blooms 1997-2000. Deep Sea Research I, 51 (12), 1803. doi:10.1016/j.dsr. 2004.07.003.

40. Moore TS, Dowell MD, Franz BA. Detection of coccolithophore blooms in ocean color satellite imagery: A generalized approach for use with multiple sensors. Remote Sensing of Environment. 2012;117:249-263.

41. Morozov, E., Pozdnyakov, D., Smyth, T., Sychev, V., Grassl, H., 2013. Space-borne study of seasonal, multi-year, and decadal phytoplankton dynamics in the Bay of Biscay. International Journal of Remote Sensing, 34, 1297-1331.doi:10.1080/01431161.2012.718462.

42. Paasche E., 2001. A review of the coccolithophorid Emiliania huxleyi (Prymnesiophyceae) with particular reference to growth, coccolith formation and calcification-photosynthesis interactions. Phycologia, 40:503-529.

43. Poulton, A. J., S. C. Painter, J. R. Young, N. R. Bates, B. Bowler, D. Drapeau, E. Lyczsckowski, Balch, W.M., 2013. The 2008 Emiliania huxleyi bloom along the Patagonian Shelf: Ecology, biogeochemistry, and cellular calcification, Global Biogeochem. Cycles, 27, 1023-1033, doi: HYPERLINK "http://dx.doi.org/10.1002/2013GB004641" In_blank10.1002/2013GB004641.

44. Raitsos, D. E., Lavender, S. J., Pradhan, Y., Tyrrell, T., Reid, P. C., \& Edwards, M., 2006. Coccolithophore bloom size variation in response to the regional environment of the subarctic North Atlantic. Limnology and Oceanography, 51(5), 2122-2130.

45. Rees, A. P., E. Malcolm, S. Woodward, C. Robinson, D. G. Cummings, G. A. Tarran, and I. 32 
Joint, 2002. Size fractionated nitrogen uptake and carbon fixation during a developing coccolithophore bloom in the North Sea during June 1999. Deep Sea Reserch, Part II, 49, 29052927, doi:10.1016/S0967-0645(02)00063-2.

46. Rose, M. (1933). Copépodes Pélagiques. Faune de France, 26, Féderation française des sociétés de sciences naturelles, Editions Lechevallier, 374 p.

47. Saulquin, B., Gohin, F., and Garrello, R., 2011. Regional Objective Analysis for Merging HighResolution MERIS, MODIS/Aqua, and SeaWiFS Chlorophyll-a Data from 1998 to 2008 on the European Atlantic Shelf. Ieee Transactions on Geoscience and Remote Sensing, 49, 143-154, 10.1109/tgrs.2010.2052813.

48. Sautour, B., Artigas, L. F., Delmas, D., Herbland, A. and Laborde, P., 2000. Grazing impact of micro- and mesozooplankton during a spring situation in coastal waters off the Gironde estuary. Journal of Plankton Research, 22, 531-552.

49. Schiebel, R., Brupbacher, U., Schmidtko, S., Nausch, G., Waniek, J.J., Thierstein, H.R., 2011. Spring coccolithophore production and dispersion in the temperate eastern North Atlantic Ocean. Journal of Geophysical Research - Oceans 116, 12.

50. Sharples, J., Moore, C.M., Hickman, A.E., Holligan, P.M., Tweddle, J.F., Palmer, M.R., Simpson, J.H., 2009. Internal tidal mixing as a control on continental margin ecosystems. Geophysical Research Letters, 36, L23603. doi:10.1029/2009GL040683.

51. Shutler, J. D., Grant, M. G., Miller, P. I., Rushton, E., and Anderson, K., 2010. Coccolithophore bloom detection in the north east Atlantic using SeaWiFS: algorithm description, application and sensitivity analysis, Remote Sens. Environ., 114, 1008-1016, doi:10.1016/j.rse.2009.12.024.

52. Strickland, J.D.H., Parsons, T.R., 1972. A practical handbook of seawater analysis. Journal of the Fisheries Research Board of Canada, 167, 47e89. 
53. Townsend, D.W., Keller, M.D., Holligan, P.M., Ackleson, S.G., Balch, W.M., 1994. Blooms of the coccolithophore Emiliania huxleyi with respect to hydrography in the Gulf of Maine. Continental Shelf Research, 14, 979-1000.

54. Tyrell, T., Merico, A., 2004. Emiliania huxleyi: bloom observations and the conditions that induce them, in: Thierstein, H.R., Young, J.R. (Eds.), Coccolithophores: From Molecular Processes to Global Impact. Springer, pp. 75-97.

55. Van der Wal, P., R. S. Kempers, and M. J. W. Veldhuis, 1995. Production and downward flux of organic matter and calcite in a North Sea bloom of the coccolithophore Emiliania huxleyi. Marine Ecology Progress Series, 126(1-3), 247-265, doi:10.3354/meps126247.

56 Westbroek, P. et al., 1993. A model approach to biological climate forcing. The example of Emiliania huxleyi. Global and Planetary Change, 8: 27-46. 